\title{
Surgical and clinical efficacy of sacroiliac joint fusion: a systematic review of the literature
}

\author{
Hasan A. Zaidi, MD, ${ }^{1}$ Andrew J. Montoure, BS, ${ }^{2}$ and Curtis A. Dickman, MD' \\ 'Department of Neurological Surgery, Barrow Neurological Institute, St. Joseph's Hospital and Medical Center; and ${ }^{2}$ Creighton \\ University School of Medicine, Phoenix Regional Campus, St. Joseph's Hospital and Medical Center, Phoenix, Arizona \\ OBJECT The sacroiliac joint (SIJ) and surgical intervention for treating SIJ pain or dysfunction has been a topic of \\ much debate in recent years. There has been a resurgence in the implication of this joint as the pain generator for \\ many patients experiencing low-back pain, and new surgical methods are gaining popularity within both the orthopedic \\ and neurosurgical fields. There is no universally accepted gold standard for diagnosing or surgically treating SIJ pain. \\ The authors systematically reviewed studies on SIJ fusion in the neurosurgical and orthopedic literature to investigate \\ whether sufficient evidence exists to support its use.
}

METHODS A literature search was performed using MEDLINE, Google Scholar, and OvidSP-Wolters Kluwer Health for all articles regarding SIJ fusion published from 2000 to 2014. Original, peer-reviewed, prospective or retrospective scientific papers with at least 2 patients were included in the study. Exclusion criteria included follow-up shorter than 1-year, nonsurgical treatment, inadequate clinical data as determined by 2 independent reviewers, non-English manuscripts, and nonhuman subjects.

RESULTS A total of 16 peer-reviewed journal articles met the inclusion criteria: 5 consecutive case series, 8 retrospective studies, and 3 prospective cohort studies. A total of 430 patients were included, of whom 131 underwent open surgery and 299 underwent minimally invasive surgery (MIS) for SIJ fusion. The mean duration of follow-up was 60 months for open surgery and 21 months for MIS. SIJ degeneration/arthrosis was the most common pathology among patients undergoing surgical intervention (present in 257 patients [59.8\%]), followed by SIJ dysfunction (79 [18.4\%]), postpartum instability (31 [7.2\%]), posttraumatic (28 [6.5\%]), idiopathic $(25[5.8 \%])$, pathological fractures $(6[1.4 \%])$, and HLA-B27+/rheumatoid arthritis (4 [0.9\%]). Radiographically confirmed fusion rates were $20 \%-90 \%$ for open surgery and $13 \%-100 \%$ for MIS. Rates of excellent satisfaction, determined by pain reduction, function, and quality of life, ranged from $18 \%$ to $100 \%$ with a mean of $54 \%$ in open surgical cases. For MIS patients, excellent outcome, judged by patients' stated satisfaction with the surgery, ranged from $56 \%$ to $100 \%$ (mean $84 \%$ ). The reoperation rate after open surgery ranged from $0 \%$ to $65 \%$ (mean 15\%). Reoperation rate after MIS ranged from $0 \%$ to $17 \%$ (mean 6\%). Major complication rates ranged from $5 \%$ to $20 \%$, with 1 study that addressed safety reporting a $56 \%$ adverse event rate.

CONCLUSIONS Surgical intervention for SIJ pain is beneficial in a subset of patients. However, with the difficulty in accurate diagnosis and evidence for the efficacy of SIJ fusion itself lacking, serious consideration of the cause of pain and alternative treatments should be given before performing the operation.

http://thejns.org/doi/abs/10.3171/2014.10.SPINE14516

KEY WORDS arthrodesis; sacroiliac joint fusion; minimally invasive; sacral

\section{$\mathrm{L}$}

ow-back pain continues to be a debilitating and common issue for much of the population. According to the National Health Interview Survey conducted in $2002,26.4 \%$ of the 31,044 respondents reported that they had had severe low-back pain some time during the previous 3 months. ${ }^{8}$ Extrapolating from those data to the current population aged 18 years or older in the United States, almost 74 million individuals are estimated to have suffered from low-back pain within the last 3 months (http://www. census.gov/popclock/), and $2.3 \%$ of all physician visits per year are estimated to be for low-back pain. ${ }^{8}$ The etiology of this pain varies greatly, ranging from primary nerve pain to degenerated discs, tumors, fractures, or any other compressive mechanism, to muscular and ligamentous origin. Recently, the medical field has experienced a resurgence in recognition of the sacroiliac joint (SIJ) as the derivation of a large number of cases of low-back pain. This focus on the SIJ as the cause of pain is a topic of much debate and

ABBREVIATIONS BMP = bone morphogenetic protein; MIS = minimally invasive surgery; SIJ = sacroiliac joint.

SUBMITTED May 22, 2014. ACCEPTED October 23, 2014.

INCLUDE WHEN CITING Published online April 3, 2015; DOI: 10.3171/2014.10.SPINE14516.

DISCLOSURE Dr. Dickman is a consultant for and receives royalties from Medtronic and DePuy Spine. 


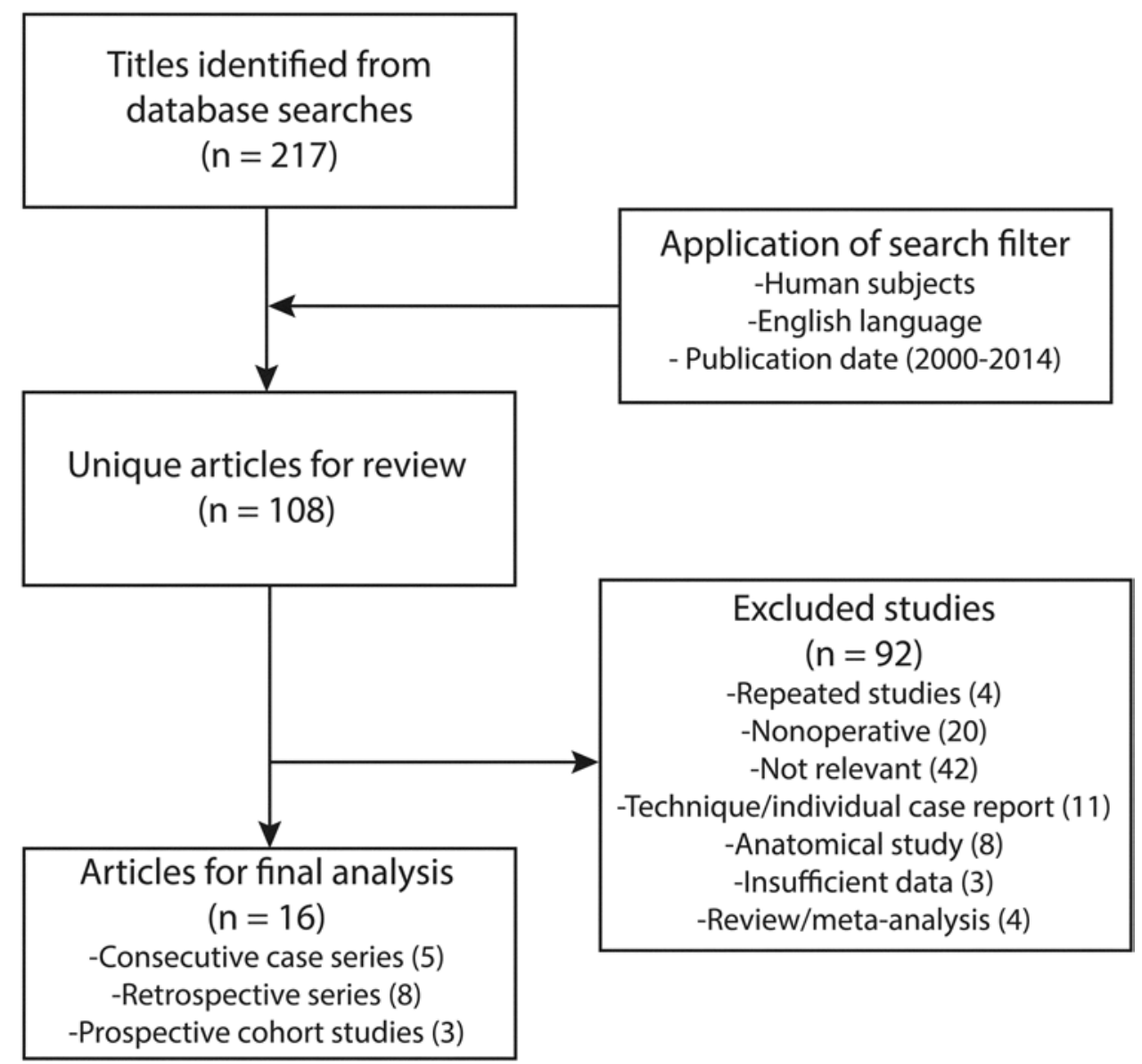

FIG. 1. Systematic review flow diagram.

interest to orthopedic surgeons and neurosurgeons alike. There is a strong consensus that $15 \%$ to $30 \%$ of low-back pain cases can be attributed to the SIJ., ${ }^{3,6,22,23}$ Even with this high prevalence, the diagnosis and treatment for SIJ pain remains a topic of disagreement, and critics argue against the efficacy of SIJ fusion as definitive treatment for individuals experiencing SIJ pain. Even so, SIJ fusion has been steadily gaining popularity among many orthopedic surgeons and neurosurgeons. We sought to perform an evidence-based systematic analysis of the published literature regarding the indications, clinical outcomes, and fusion rates associated with SIJ fixation to help guide future clinical practice.

\section{Methods}

An extensive literature search was performed using MEDLINE, Google Scholar, and OvidSP-Wolters Kluwer Health search engines. All articles containing the keywords "sacroiliac fusion," "minimally invasive sacroiliac joint fusion," "sacroiliac joint arthrodesis," or "sacroiliac fixation" published from January 2000 to May 2014 were reviewed by 2 independent investigators. Original, peerreviewed, prospective or retrospective scientific papers including at least 2 cases were included in the study. Exclusion criteria included inadequate clinical data as determined by 2 independent reviewers, nonsurgical treatment,
non-English manuscripts, and nonhuman subjects. If a publication by a single institution or author clearly reported on the same cohort of patients as another publication, only the most recently published article with the largest sample size was included for final analysis. Two investigators independently reviewed each article, and data were extracted for the following variables: study design, total number of patients, surgical indications and pathological findings, previous surgical intervention, fusion rates, complication rates, perioperative morbidity, patient satisfaction rates and type of outcome assessment tools used, surgical procedure performed (open vs minimally invasive), inclusion criteria for surgery, and method of diagnosis of SIJ-generated pain.

A total of 217 articles were identified from the online database searches. After filtering reports that only contained human subjects, English-language publications, and published date from January 2000 to May 2014, a total of 108 unique articles were available for review. Of these 108 studies, 92 were eliminated for the following reasons: repeated studies $(n=4)$, nonoperative/diagnostic studies $(\mathrm{n}=20)$, not relevant to SIJ fusion $(\mathrm{n}=42)$, technique/ individual case reports $(n=11)$, anatomical studies $(n=8)$, insufficient data $(n=3)$, and reviews/meta-analysis $(n=4)$ (Fig. 1). A total of 16 peer-reviewed journal articles were found: 5 consecutive case series, 8 retrospective studies, and 3 prospective cohort studies. Seven of the studies re- 
TABLE 1. Open surgery

\begin{tabular}{|c|c|c|c|c|c|c|}
\hline $\begin{array}{l}\text { Authors \& } \\
\quad \text { Year }\end{array}$ & $\begin{array}{l}\text { Type of } \\
\text { Study }\end{array}$ & $\begin{array}{l}\text { No. of } \\
\text { Pts }\end{array}$ & $\begin{array}{l}\text { Follow-Up } \\
\text { (range) })^{*}\end{array}$ & Inclusion Criteria† & Pathology & Surgical Technique \\
\hline $\begin{array}{l}\text { Belanger \& } \\
\quad \text { Dall, } 2001\end{array}$ & $\begin{array}{l}\text { Consecutive } \\
\text { case study }\end{array}$ & 4 & $\begin{array}{c}6 \text { (6 mos- } \\
9 \mathrm{yrs})\end{array}$ & $\begin{array}{l}\text { Pos physical exam, pain } \\
\text { relief w/ image-guided } \\
\text { SIJ injection }\end{array}$ & $\begin{array}{l}\text { RA joint disruption (1/4), } \\
\text { symptomatic SI arthrosis } \\
(3 / 4)\end{array}$ & $\begin{array}{r}\text { Midline posterior approach, } \\
\text { pedicle screw, autograft }\end{array}$ \\
\hline $\begin{array}{l}\text { Berthelot et } \\
\quad \text { al., } 2001\end{array}$ & Case reports & 2 & $30(24-36)$ & $\begin{array}{l}\text { Pain relief } w / \text { image-guided } \\
\text { SIJ injection }\end{array}$ & $\begin{array}{l}\text { HLA-B27+ spondylarthropa- } \\
\text { thy (bilat } 1 / 2 \text { ) }\end{array}$ & $\begin{array}{l}\text { Posterior approach, pedicle } \\
\text { screws, autograft }\end{array}$ \\
\hline $\begin{array}{l}\text { Giannikas et } \\
\text { al., } 2004\end{array}$ & $\begin{array}{l}\text { Consecutive } \\
\text { case study }\end{array}$ & 5 & $29(25-41)$ & $\begin{array}{l}\text { Pain relief w/ image-guided } \\
\text { SIJ injection, bone scan, } \\
\text { physical exam }\end{array}$ & $\begin{array}{l}\text { Traumatic (4/5), idiopathic } \\
\quad(1 / 4)\end{array}$ & $\begin{array}{l}\text { Posterior approach, fusion } \\
\text { w/ Cloward instrumenta- } \\
\text { tion }\end{array}$ \\
\hline $\begin{array}{l}\text { Buchowski et } \\
\text { al., } 2005\end{array}$ & $\begin{array}{l}\text { Retrospective } \\
\text { review }\end{array}$ & 20 & $70(24-108)$ & $\begin{array}{l}\text { Pain relief w/ image-guided } \\
\text { SIJ injection, physical } \\
\text { exam }\end{array}$ & $\begin{array}{l}\text { SIJ dysfunction }(13 / 20) \text {, } \\
\text { SI osteoarthritis }(5 / 20) \text {, } \\
\text { HLA-B27 + (1/20), SI } \\
\text { postpartum instability } \\
(1 / 20)\end{array}$ & $\begin{array}{l}\text { Modified Smith-Petersen } \\
\text { technique, T or L plate } \\
\text { \& screw stabilization, } \\
\text { autograft }\end{array}$ \\
\hline $\begin{array}{l}\text { Schütz \& } \\
\text { Grob, } 2006\end{array}$ & $\begin{array}{l}\text { Retrospective } \\
\text { review }\end{array}$ & 17 & $39(12-66)$ & $\begin{array}{l}\text { Pos physical exam, radio- } \\
\text { graphic confirmation, } \\
\text { pain relief w/ SIJ injection } \\
(14 / 17)\end{array}$ & $\begin{array}{l}\text { Idiopathic degeneration } \\
(12 / 17), \text { post-traumatic } \\
(5 / 17)\end{array}$ & Bilat Buttress, autograft \\
\hline $\begin{array}{l}\text { Ebraheim et } \\
\text { al., } 2010\end{array}$ & $\begin{array}{l}\text { Consecutive } \\
\text { case study }\end{array}$ & 11 & $18(12-48)$ & Pain relief w/ SIJ injection & $\begin{array}{l}\text { Posttraumatic + failed per- } \\
\text { cutaneous screw fixation } \\
(11 / 11)\end{array}$ & $\begin{array}{l}\text { Posterior approach, fibular } \\
\text { bone grafting }\end{array}$ \\
\hline $\begin{array}{l}\text { Kibsgård et } \\
\text { al., } 2013\end{array}$ & $\begin{array}{l}\text { Retrospective } \\
\text { review }\end{array}$ & 50 & $276(156-408)$ & $\begin{array}{l}\text { Pos physical exam, radio- } \\
\text { logical confirmation }\end{array}$ & $\begin{array}{l}\text { Postpartum instabil- } \\
\text { ity }(30 / 50) \text {, idiopathic } \\
(12 / 50) \text {, posttraumatic } \\
(8 / 50) \text {, bilateral }(29 / 50)\end{array}$ & $\begin{array}{l}\text { Posterior approach, trans- } \\
\text { iliac, or intra-articular } \\
\text { fusion, autograft }\end{array}$ \\
\hline $\begin{array}{l}\text { Ledonio et al., } \\
2014\end{array}$ & $\begin{array}{l}\text { Retrospective } \\
\text { review }\end{array}$ & 22 & $13(11-33)$ & $\begin{array}{l}\text { Pain relief w/ image-guided } \\
\text { SIJ injection }\end{array}$ & $\begin{array}{l}\text { SIJ dysfunction or sacroili- } \\
\text { itis }(22 / 22)\end{array}$ & $\begin{array}{l}\text { Anterior approach, 3-hole } \\
\text { plate, autograft }\end{array}$ \\
\hline
\end{tabular}

Exam = examination; pos = positive; pts = patients; $\mathrm{RA}=$ rheumatoid arthritis $; \mathrm{SI}=$ sacroiliac.

* Values are in months unless otherwise indicated.

$\dagger$ All patients failed conservative treatment.

viewed an open technique for SIJ fusion, $2,4,5,10,12,14,218$ reviewed a minimally invasive approach, ${ }^{1,7,9,13,18-20,25}$ and 1 study compared the 2 different techniques. ${ }^{15}$

\section{Results}

The total number of patients included in this review was 430; 131 underwent an open technique for SIJ fusion (Table 1) and 299 underwent minimally invasive surgery (MIS) (Table 2). The average duration of follow-up was 60 months for open surgery (range 6-408 months) and 21 months for MIS (range 6-70 months). The pathological finding most commonly described in the overall patient population included in this review was SIJ degeneration or arthrosis (257 patients [59.8\%]), followed by SIJ dysfunction (79 [18.4\%]), postpartum instability (31 [7.2\%]), posttraumatic injury (28 [6.5\%]), and idiopathic disease (25 [5.8\%]) (Table 3). Of the studies reviewed, 12 of 16 specified whether previous back surgery occurred. Reviewing these 12 studies, 201 patients (63.4\%) had some form of low-back surgery before undergoing the reported SIJ fusion (Table 4).

For the open surgery technique, fusion confirmation was determined by CT scan, and success rates ranged from $20 \%$ to $90 \%$. Clinical and patient satisfaction was based on several subjective patient assessment tools. Excellent satisfaction, determined by pain reduction, function, and quality of life, ranged from $18 \%$ to $100 \%$, with a mean of 54\%. Poor satisfaction rates (e.g., patient stating he/she would rather have not had the surgery) ranged from $0 \%$ to $47 \%$, with a mean of $32 \%$ of patients classified as dissatisfied with the surgical outcome (Table 5). For patients undergoing MIS, fusion was determined in 4 of 9 studies by either CT or plain radiograph, and confirmation rates ranged from $13 \%$ to $100 \%$. Clinical and patient satisfaction scores were determined by subjective questionnaires and pain improvement. Excellent outcome, judged by a patient's stated satisfaction with the surgery, ranged from $56 \%$ to $100 \%$, with a mean of $84 \%$ (Table 6).

The reoperation rate for patients undergoing open surgery ranged from $0 \%$ to $65 \%$, with a mean of $15 \%$. The major complications after open surgery were painful hardware leading to removal, deep wound or pin infections, and nerve root irritation (Table 7). Other complications encountered were localized muscle herniation at the autograft site, peroneal nerve entrapment, neurolysis, an intraoperative iliac crest fracture, and pulmonary emboli.

The reoperation rate for patients undergoing MIS ranged from $0 \%$ to $17 \%$, with a mean of $6 \%$. Major com- 
TABLE 2. Minimally invasive technique

\begin{tabular}{|c|c|c|c|c|c|c|}
\hline $\begin{array}{l}\text { Authors \& } \\
\text { Year }\end{array}$ & $\begin{array}{l}\text { Type of } \\
\text { Study }\end{array}$ & $\begin{array}{l}\text { No. of } \\
\text { Pts }\end{array}$ & $\begin{array}{l}\text { Follow-Up } \\
\text { (range)* }\end{array}$ & Inclusion Criteria† & Pathology & Surgical Technique \\
\hline $\begin{array}{l}\text { Al-Khayer et al., } \\
2008\end{array}$ & $\begin{array}{l}\text { Consecutive } \\
\text { case study }\end{array}$ & 9 & $40(24-70)$ & $\begin{array}{l}\text { Pain relief w/ image-guided SIJ } \\
\text { injection }\end{array}$ & Chronic SIJ pain (3/9 bilat) & $\begin{array}{l}\text { HMA screw w/ autograft, } \\
\text { BMP-2 }\end{array}$ \\
\hline $\begin{array}{l}\text { Wise \& Dall, } \\
\quad 2008\end{array}$ & $\begin{array}{l}\text { Prospective } \\
\text { cohort }\end{array}$ & 13 & $29(24-35)$ & $\begin{array}{l}\text { Pain relief w/ image-guided SIJ } \\
\text { injection }\end{array}$ & Chronic SIJ pain (6/13 bilat) & $\begin{array}{l}\text { Two longitudinal threaded } \\
\text { cages w/ BMP }\end{array}$ \\
\hline $\begin{array}{l}\text { Khurana et al., } \\
2009\end{array}$ & $\begin{array}{l}\text { Consecutive } \\
\text { case study }\end{array}$ & 15 & $17(9-39)$ & $\begin{array}{l}\text { Pain relief w/ image-guided SIJ } \\
\text { injection, physical exam }\end{array}$ & SIJ degeneration & HMA screws \\
\hline $\begin{array}{l}\text { Papanastassiou } \\
\text { et al., } 2011\end{array}$ & $\begin{array}{l}\text { Retrospective } \\
\text { review }\end{array}$ & 6 & $19(12-30)$ & $\begin{array}{l}\text { Clinical \& radiologic confirma- } \\
\text { tion }\end{array}$ & $\begin{array}{l}\text { Sacral insufficiency frac- } \\
\text { tures in cancer pts }\end{array}$ & $\begin{array}{l}\text { Multiple long screws that } \\
\text { cross both SI joints \& } \\
\text { engage iliac bones }\end{array}$ \\
\hline Rudolf, 2012 & $\begin{array}{l}\text { Retrospective } \\
\text { review }\end{array}$ & 50 & $40(24-56)$ & $\begin{array}{l}\text { Pain relief w/ image-guided SIJ } \\
\text { injection, physical exam }\end{array}$ & $\begin{array}{l}\text { Degenerative sacroiliitis } \\
\text { (5/50 bilat) }\end{array}$ & iFuse Implant System‡ \\
\hline $\begin{array}{l}\text { Cummings \& } \\
\text { Capobianco, } \\
2013\end{array}$ & $\begin{array}{l}\text { Retrospective } \\
\text { review }\end{array}$ & 18 & 12 & $\begin{array}{l}\text { Pain relief w/ image-guided SIJ } \\
\text { injection, physical exam }\end{array}$ & $\begin{array}{l}\text { Degenerative sacroiliitis or } \\
\text { SIJ disruption }\end{array}$ & iFuse Implant System $\ddagger$ \\
\hline $\begin{array}{l}\text { Duhon et al., } \\
2013\end{array}$ & $\begin{array}{l}\text { Prospective } \\
\text { cohort }\end{array}$ & $94,32 \S$ & 6 & $\begin{array}{l}\text { Pain relief w/ image-guided SIJ } \\
\text { injection, pos provocative } \\
\text { testing }\end{array}$ & $\begin{array}{l}\text { Degenerative sacroiliitis or } \\
\text { SIJ disruption }\end{array}$ & iFuse Implant System $\ddagger$ \\
\hline $\begin{array}{r}\text { Sachs \& Capo- } \\
\text { bianco, } 2013\end{array}$ & $\begin{array}{l}\text { Prospective } \\
\text { cohort }\end{array}$ & 40 & 12 & $\begin{array}{l}\text { Pain relief w/ image-guided SIJ } \\
\text { injection, physical exam }\end{array}$ & $\begin{array}{l}\text { Degenerative sacroiliitis or } \\
\text { SIJ disruption ( } 1 / 40 \text { bilat) }\end{array}$ & iFuse Implant System $\ddagger$ \\
\hline $\begin{array}{l}\text { Ledonio et al., } \\
\qquad 2014\end{array}$ & $\begin{array}{l}\text { Retrospective } \\
\text { review }\end{array}$ & 22 & $15(12-26)$ & $\begin{array}{l}\text { Pain relief w/ image-guided SIJ } \\
\text { injection }\end{array}$ & $\begin{array}{l}\text { SIJ dysfunction or sacroi- } \\
\quad \text { liitis }\end{array}$ & iFuse Implant System $\ddagger$ \\
\hline \multicolumn{7}{|c|}{$\begin{array}{l}\text { BMP-2 = bone morphogenetic protein-2; HMA = hollow modular anchorage. } \\
\text { * Values are in months unless otherwise indicated. } \\
\dagger \text { Conservative treatment had failed in all cases. } \\
\text { † Triangular porous titanium implants sprayed with plasma. } \\
\S \text { There were } 94 \text { patients in the safety cohort and } 32 \text { in the effectiveness cohort. }\end{array}$} \\
\hline
\end{tabular}

plications encountered after MIS were new-onset facet joint pain, trochanteric bursitis, deep wound infections, new onset of low-back or leg pain, and superficial cellulitis (Table 8). Other complications encountered were radiculopathy, vascular necrosis of the hip, piriformis syndrome, implant penetration into the sacral neural foreman, peripheral neuropathy, a nondisplaced fracture, and pulmonary emboli/deep vein thrombosis. One study reported the adverse event rate at $56 \%$.

\section{Discussion}

The recognition of SIJ pain as the origin of persistent,

TABLE 3. Pathological findings in 430 patients undergoing SIJ fusion

\begin{tabular}{lc}
\hline \multicolumn{1}{c}{ Pathology } & No. of Pts (\%) \\
\hline SIJ degeneration/arthrosis & $257(59.8)$ \\
\hline SIJ dysfunction & $79(18.4)$ \\
\hline Postpartum instability & $31(7.2)$ \\
\hline Posttraumatic injury & $28(6.5)$ \\
\hline Idiopathic disease & $25(5.8)$ \\
\hline Pathological fractures & $6(1.4)$ \\
\hline HLA-B27+ & $3(0.7)$ \\
\hline RA & $1(0.2)$ \\
\hline
\end{tabular}

debilitating, low-back pain is making a resurgence; similarly so is surgical intervention, fusing the SIJ by either open or minimally invasive means. Literature is scarce when it comes to describing the efficacy of surgical intervention, ${ }^{22}$ and the general consensus is to refrain from surgery until all nonoperative treatment modalities have been exhausted. ${ }^{1,2,5,12,14,15,19,22,25}$ Conservative methods for managing SIJ pain include trials of physical therapy, focusing on core and pelvic stability, external orthotics, pain management, periodic intra-articular injections, anti-inflammatory medications, and life style changes including smoking cessation and weight loss., ${ }^{9,22}$ Whether efficacy is determined by objective measures, CT-confirmed fusion, or subjective methods, patients' levels of satisfaction with the results of fusion procedures are inconsistent. In this literature analysis, confirmed fusion rates, patient satisfaction, and reoperation rates varied greatly. A majority of the patient population had a history of a previous low-back surgery before SIJ fusion, with many undergoing concomitant surgery or additional back surgery during their follow-up period. ${ }^{18,20}$ This raises the question of where the true pain generator lies. Ultimately the goal for future practice is to develop screening techniques that can accurately diagnosis whether the SIJ is the pain generator, as a filter to selecting appropriate treatment for patients.

The first step to successful clinical outcomes is obtaining an accurate diagnosis. While historically the diagnosis of SIJ pain has been difficult to make, all but one of the 
TABLE 4. Patients with history of low-back surgery before SIJ fusion

\begin{tabular}{|c|c|c|c|}
\hline Authors \& Year & $\begin{array}{l}\text { No. of } \\
\text { Pts }\end{array}$ & $\begin{array}{l}\% \text { of Study } \\
\text { Population }\end{array}$ & $\begin{array}{l}\text { Previous Surgical } \\
\text { Intervention* }\end{array}$ \\
\hline $\begin{array}{l}\text { Belanger \& Dall, } \\
2001\end{array}$ & $3 / 4$ & $75 \%$ & Lumbosacral fusion (3) \\
\hline $\begin{array}{l}\text { Buchowski et al., } \\
2005\end{array}$ & $15 / 20$ & $75 \%$ & $\begin{array}{l}\text { Lumbar fusion (10) } \\
\text { Decompression (8) } \\
\text { Removal of hardware } \\
\quad(3) \\
\text { Lumbar discectomy (2) } \\
\text { SIJ arthrodesis (1) } \\
\text { Repair of lumbar pars } \\
\quad \text { defect (1) }\end{array}$ \\
\hline $\begin{array}{l}\text { Schütz \& Grob, } \\
2006\end{array}$ & $10 / 17$ & $59 \%$ & $\begin{array}{l}\text { Lumbar fusion (10) } \\
\text { Discectomy (9) } \\
\text { Removal of hardware } \\
(5) \\
\text { Lumbar decompres- } \\
\text { sion (4) } \\
\text { SIJ fusion (1) }\end{array}$ \\
\hline Wise \& Dall, 2008 & $8 / 13$ & $62 \%$ & $\begin{array}{l}\text { Lumbar fusion (8) } \\
\text { Contralateral SIJ fusion } \\
\text { (1) }\end{array}$ \\
\hline $\begin{array}{l}\text { Ebraheim et al., } \\
2010\end{array}$ & $11 / 11$ & $100 \%$ & $\begin{array}{l}\text { Percutaneous SIJ fusion } \\
\text { (11) }\end{array}$ \\
\hline $\begin{array}{l}\text { Papanastassiou et } \\
\text { al., } 2011\end{array}$ & $3 / 6$ & $50 \%$ & $\begin{array}{l}\text { Sacrectomy (2) } \\
\text { Sacroplasty (2) } \\
\text { Sacroiliac pinning (1) }\end{array}$ \\
\hline Rudolf, 2012 & $22 / 50$ & $44 \%$ & Lumbar fusion (22) \\
\hline $\begin{array}{l}\text { Cummings \& Capo- } \\
\text { bianco, } 2013\end{array}$ & $15 / 18$ & $83 \%$ & $\begin{array}{l}\text { Lumbar fusion (11) } \\
\text { Decompression (2) } \\
\text { Microdissection (2) }\end{array}$ \\
\hline Duhon et al., 2013 & $70 / 94$ & $56 \%$ & Lumbar fusion (70) \\
\hline $\begin{array}{l}\text { Sachs \& Capobi- } \\
\text { anco, } 2013\end{array}$ & $19 / 40$ & $48 \%$ & Lumbar surgery (19) \\
\hline $\begin{array}{l}\text { Ledonio et al., } 2014 \\
\text { (open surgery) }\end{array}$ & $11 / 22$ & $50 \%$ & NA \\
\hline $\begin{array}{l}\text { Ledonio et al., } 2014 \\
\text { (MIS) }\end{array}$ & $14 / 22$ & $64 \%$ & NA \\
\hline Total (12/16 articles) & $201 / 317$ & $63.4 \%$ & \\
\hline
\end{tabular}

NA = not available.

* Some patients had more than 1 surgical intervention.

studies (94\%) in this review used patient relief from pain after intra-articular joint anesthetic or steroid injection as the ultimate factor for inclusion in an SIJ fusion protocol (Tables 1 and 2). Most screenings were completed under fluoroscopic guidance to ensure accurate placement of the injection. A positive result was pain reduction by $50 \%$ to $100 \%$, depending on the specific study, after the injection. ${ }^{1,2,4,5,7,9,10,12,13,15,19-21,25}$

Cohen described the various modalities used for diagnosing SIJ pain-physical examination, radiological studies, pain referral patterns, and diagnostic blocks-in a comprehensive review and came to the conclusion that there is no single universally accepted diagnostic method. ${ }^{6}$ Factors that can affect the sensitivity and specificity of diagnostic blocks include a placebo effect, referred pain, central sensitization, expectation bias, symptomatic blockade, systemic absorption, and psychosocial issues. ${ }^{6}$ Although the studies analyzed here suggest a positive response to SIJ block as the final diagnostic inclusion criterion, along with physical examination or radiological studies, there is a drastic lack of literature evidence to support such a conclusion in the literature. ${ }^{24}$

SIJ injection is considered the best test currently available for diagnosing SIJ as the cause of low-back pain, so it is the adopted gold standard; however, there is still considerable error in relying on this method alone. To improve diagnostic precision, some authors advocate the use of the double-block standard. ${ }^{21}$ This method repeats the positive block with a different substance to improve sensitivity of the test. In summary, however, the use of physical examination, radiological studies, or diagnostic blocks cannot diagnose the SIJ as the origin of pain with a reasonably accepted sensitivity or specificity.

With questionable diagnostic precision and the high rate of previous low-back surgeries, concomitant surgeries, and eventual future surgeries among patients undergoing SIJ fusion, one must seriously consider whether the SIJ is the actual pain generator for many patients. Prior history of back surgery reached nearly $60 \%$ among patients undergoing SIJ fusion in the 16 publications included here ${ }^{2,5,7,9,10,15,18-21,25}$ along with 6 reported cases of concomitant low-back surgeries. ${ }^{18,20}$ A few studies demonstrated the possible phenomenon of non-SIJ causes of pain, with relatively high fusion rates $(85 \%-90 \%)$ but comparatively poor patient-rated success $(48 \%-60 \%))^{5,14}$

The SIJ is a complex joint that transmits force from the spine down to the pelvis and lower extremities as well as from the pelvis and lower extremities up to the spine, ${ }^{11}$ closely associating the SIJ with the lumbar spine superiorly and the knee joint inferiorly. This relationship is confirmed with the well-accepted association of SIJ pain after lumbar spine fusion. Maigne and Planchon demonstrated that $35 \%$ of pain after lumbar fusion could be attributed to the SIJ, ${ }^{17}$ while Liliang et al. confirmed the SIJ as the origin of pain after lumbar fusion in $40 \%$ of their population. ${ }^{16}$ One of the most commonly stated etiologies for SIJ pain is sacroiliac joint dysfunction, which is defined by pain without a demonstrable lesion. ${ }^{4}$ There is a presumed mechanical disorder, but taking into account the lack of certainty in diagnostic methods and complexity of the hip and SIJ, an alternative origin of the discomfort is a very reasonable consideration. The pain and discomfort experienced by the cohort described in this manuscript is likely a combination of various pathologies, specifically with lumbar, hip, and lower-extremity etiologies.

There is no universally accepted method for surgical intervention in the treatment of SIJ pain or instability. Many open methods have been described through short case series, and the new approaches to MIS have made a recent splash in the literature. The Smith-Petersen technique uses an iliac autograft fixated within the SIJ with atlanto-occipital screws. ${ }^{4,19}$ Other techniques described in our literature search are a midline posterior approach us- 
TABLE 5. Patient outcome and satisfaction rates for open surgery technique

\begin{tabular}{|c|c|c|c|c|c|}
\hline Authors \& Year & Outcome Assessment Tools & $\begin{array}{l}\text { Fusion Rate } \\
\text { (if available) }\end{array}$ & $\begin{array}{l}\text { Nonunion Rate } \\
\text { (if available) }\end{array}$ & Satisfaction & $\begin{array}{l}\text { Reoperation } \\
\text { Rate }(\%)\end{array}$ \\
\hline Belanger \& Dall, 2001 & $\begin{array}{l}\text { Satisfactory assessment } \\
\text { questionnaire (pain, mobil- } \\
\text { ity, function) }\end{array}$ & $\begin{array}{l}2 / 4(50 \%) \text { w/ CT confir- } \\
\text { mation, } 4 / 4(100 \%) \\
\text { clinically }\end{array}$ & & $\begin{array}{l}3 / 4(75 \%) \text { satisfied, } 4 / 4(100 \%) \\
\quad \text { residual SI discomfort }\end{array}$ & 25 \\
\hline Berthelot et al., 2001 & Patient verbal satisfaction & & & $2 / 2(100 \%)$ satisfied & 0 \\
\hline Giannikas et al., 2004 & VAS & $\begin{array}{l}1 / 5(20 \%) \text { had postop } \\
\text { imaging }\end{array}$ & & $4 / 5(80 \%)$ satisfied & \\
\hline Buchowski et al., 2005 & SF-36, AAOS MODEM & $\begin{array}{l}\text { 17/20 (85\%), w/ no CT } \\
\text { confirmation }\end{array}$ & $3 / 20(15 \%)$ & $\begin{array}{l}12 / 20(60 \%) \text { would have surgery } \\
\text { again }\end{array}$ & 15 \\
\hline Schütz \& Grob, 2006 & $\begin{array}{l}\text { Pain improvement-short \& } \\
\text { long term }\end{array}$ & $\begin{array}{c}6 / 17(35 \%), 4 / 17(23 \%) \\
\text { questionable fusion }\end{array}$ & $7 / 17(41 \%)$ & $\begin{array}{l}3 / 17(18 \%) \text { satisfied, } 6 / 17(35 \%) \\
\text { rated fair outcome, } 8 / 17(47 \%) \\
\text { rated poor outcome }\end{array}$ & 65 \\
\hline Ebraheim et al., 2010 & Pain, ambulation & $\begin{array}{l}3 / 11(27 \%) \text { w/ CT confir- } \\
\text { mation }\end{array}$ & & $8 / 11(73 \%)$ satisfied & $0 \dagger$ \\
\hline Kibsgård et al., 2013 & VAS, SF-36, ODI & $75 / 83(90 \%)$ & $8 / 83(10 \%)$ & $\begin{array}{l}24 / 50(48 \%) \text { excellent, } 12 / 50 \\
(24 \%) \text { fair, } 14 / 50(28 \%) \text { poor }\end{array}$ & 8.4 \\
\hline $\begin{array}{l}\text { Ledonio et al., } 2014 \\
\text { (open) }\end{array}$ & ODI & & & $15 / 22(68 \%)$ improved & 9 \\
\hline
\end{tabular}

AAOS = American Academy of Orthopaedic Surgeons; MODEM = Musculoskeletal Outcomes Data Evaluation and Management System; ODI = Oswestry Disability Index; SF-36 = 36-Item Short Form Health Survey; VAS = visual analog scale for pain .

${ }^{*}$ Multiple levels were fused in some patients.

† All 11 patients in the study had prior percutaneous SIJ fusion; open SIJ fusion patients in the reported study had no reoperations.

ing pedicle screws and an autograft, or Cloward instrumentation; $2,4,10,12,14$ an anterior approach with 3-hole plate and autograft: ${ }^{15}$ and a bilateral Buttress with autograft ${ }^{21}$ (Table 1). The MIS procedures included use of hollow modular anchorage screws, autograft, and bone morphogenetic protein (BMP), ${ }^{1,13}$ longitudinally threaded cages with BMP, ${ }^{25}$ multiple long screws crossing both SIJs engaging the iliac bones, ${ }^{18}$ and the iFuse Implant System (SI-BONE) ${ }^{7,9,15,19,20}$ (Table 2).

The iFuse Implant System is rapidly gaining popularity. It is a minimally invasive surgical option that uses 3 triangular implants that are porous and coated with plas-

TABLE 6. Patient outcome and satisfaction rates with MIS

\begin{tabular}{|c|c|c|c|c|c|}
\hline Authors \& Year & Outcome Assessment Tools & $\begin{array}{l}\text { Fusion Rate } \\
\text { (if available) }^{*}\end{array}$ & $\begin{array}{l}\text { Nonunion Rate } \\
\text { (if available) }\end{array}$ & Satisfaction & $\begin{array}{l}\text { Reoperation } \\
\text { Rate }(\%)\end{array}$ \\
\hline Al-Khayer et al., 2008 & Plain radiograph, ODI, VAS & $\begin{array}{l}9 / 9(100 \%) \text { plain } \\
\text { radiograph }\end{array}$ & 0 & $\begin{array}{l}\text { Average satisfaction score: } \\
6.8 / 10\end{array}$ & \\
\hline Wise \& Dall, 2008 & $\begin{array}{l}\text { Radiographic assessment } \\
\text { for fusion, VAS }\end{array}$ & $17 / 19(89 \%)$ & $2 / 19(11 \%)$ & 10/13 (77\%) satisfied & 5 \\
\hline Khurana et al., 2009 & $\begin{array}{l}\text { SF-36, Majeed scoring } \\
\text { system }\end{array}$ & $\begin{array}{l}2 / 15(13 \%) \text { w/ CT } \\
\text { confirmation }\end{array}$ & & 13/15 (87\%) satisfied & \\
\hline Papanastassiou et al., 2011 & KPS, 10-point pain scale & & & Median pain relief: 5.6 points & 17 \\
\hline Rudolf, 2012 & SF-36, ODI, NRS 1-10 & $\begin{array}{l}52 / 55(95 \%) \text { "CT bone } \\
\text { ingrowth" }\end{array}$ & & $\begin{array}{l}19 / 27(71 \%) \text { satisfied at } 12 \text { mos } \\
5 / 27(18 \%) \text { dissatisfied at } 24 \text { mos }\end{array}$ & 8 \\
\hline $\begin{array}{l}\text { Cummings \& Capobianco, } \\
2013\end{array}$ & VAS, ODI, SF-12 & & & $\begin{array}{l}\text { 10/18 (56\%) very satisfied, } 7 / 18 \\
(39 \%) \text { somewhat satisfied, } \\
2 / 18(11 \%) \text { would not have } \\
\text { surgery again }\end{array}$ & 6 \\
\hline Duhon et al., 2013 & VAS, ODI, SF-36, EQ-5D & & & $22 / 26(85 \%)$ satisfied & 0 \\
\hline Sachs \& Capobianco, 2013 & $\begin{array}{l}\text { Pain NRS, yes/no satisfac- } \\
\text { tion }\end{array}$ & & & $40 / 40(100 \%)$ satisfied & 0 \\
\hline Ledonio et al., 2014 (MIS) & ODI & & & $16 / 22(73 \%)$ satisfied & 9 \\
\hline
\end{tabular}

EQ-5D = EuroQol-5 Dimensions; KPS = Karnofsky Performance Status; NRS = Numerical Rating System.

${ }^{*}$ Multiple levels were fused in some patients. 
TABLE 7. Major complications in 131 patients treated with open surgery

\begin{tabular}{lc}
\hline \multicolumn{1}{c}{ Complication } & $\begin{array}{c}\text { No. of Incidents } \\
\text { (no./100 cases) }\end{array}$ \\
\hline Painful hardware leading to removal & $13(9.9)$ \\
\hline Deep wound/pin infection & $3(2.3)$ \\
\hline Nerve root irritation & $2(1.5)$ \\
\hline Localized muscle herniation at autograft site & $2(1.5)$ \\
\hline Pulmonary embolism & $2(1.5)$ \\
\hline Peroneal nerve entrapment & $1(0.8)$ \\
\hline Neurolysis & $1(0.8)$ \\
\hline Intraop dorsal iliac crest fracture & $1(0.8)$ \\
\hline
\end{tabular}

ma. Five of the studies analyzed here used this approach and reported moderately successful outcomes. However, $80 \%$ of the studies did not include image-confirmed anatomical fusion as part of the outcome assessment. Other issues include short follow-up periods ranging from 6 to 40 months, and several potential conflicts of interest.7,9,15,19,20 Longer follow-up, third-party investigation, and randomized control studies are needed to assess the true efficacy for this up-and-coming intervention.

A true arthrodesis requires apposition of 2 bone surfaces, allowing for approximation without compromising the stability of the joint. ${ }^{24}$ The anatomical position of the SIJ and complex innervation make a routine joint fusion more difficult to accomplish. ${ }^{22,24}$ This has resulted in high rates of nonunion or questionable fusion and elevates the complication risk in both open and minimally invasive approaches. Duhon et al. described an adverse event rate of $56 \%$ in his safety cohort, 53 events occurring in 94 patients. ${ }^{9}$

TABLE 8. Major complications in 299 patients treated with MIS

\begin{tabular}{lc}
\hline \multicolumn{1}{c}{ Complication } & $\begin{array}{c}\text { No. of Incidents } \\
\text { (no./100 cases) }\end{array}$ \\
\hline New-onset facet joint pain & $8(2.7)$ \\
\hline Trochanteric bursitis & $7(2.3)$ \\
\hline Deep wound infection & $5(1.7)$ \\
\hline New-onset low-back/buttocks pain & $5(1.7)$ \\
\hline Worsening leg/knee pain & $5(1.7)$ \\
\hline Superficial cellulitis & $4(1.3)$ \\
\hline Radiculopathy & $3(1.0)$ \\
\hline Large hematomas & $3(1.0)$ \\
\hline Vascular necrosis of hip & $2(0.7)$ \\
\hline Piriformis syndrome & $2(0.7)$ \\
\hline Implant penetration into sacral neural foramen & $2(0.7)$ \\
\hline Peripheral neuropathy & $1(0.3)$ \\
\hline Nondisplaced fracture & $1(0.3)$ \\
\hline Pulmonary embolism & $1(0.3)$ \\
\hline DVT & $1(0.3)$ \\
\hline
\end{tabular}

DVT = deep vein thrombosis.
There are many reported cases of successful SIJ arthrodesis that greatly improve the quality of life for the individuals and eliminate their daily pain. ${ }^{1,2,4,5,7,9,10,12-15,18-}$ ${ }^{21,25}$ Certain etiologies - for example, acute traumatic instability-require immediate surgical intervention and have good reported outcomes; however, the majority of patients undergoing surgery are classified as having SIJ degeneration or dysfunction, and the consensus on efficacy of fusion is not as clear for these patients. To limit the amount of nonunion, unsatisfactory results, reoperations, and need for additional back surgery, a strict guideline for SIJ fusion needs to be developed and implemented. Kibsgård et al. compared the long-term results (mean follow-up 279 months) in 50 patients undergoing surgical intervention for their SIJ dysfunction with the follow-up of 28 patients whose cases were only managed conservatively. His review demonstrated that the surgical group did not differ from the conservative management group with respect to outcome at long-term follow-up. ${ }^{14}$ This finding reiterates the fact that surgical intervention for SIJ pathologies may not be beneficial for everyone. Accurate diagnosis, superior surgical skills, and the right patient population can make SIJ arthrodesis a worthwhile and life-changing procedure; however, these factors are not thoroughly demonstrated in much of the population undergoing the surgery today.

\section{Conclusions}

Surgical intervention for SIJ pain is beneficial in a subset of patients. However, with the difficulty in accurate diagnosis and lack of evidence for the efficacy of the procedure itself, serious consideration of the cause of pain and treatment alternatives should be made before performing SIJ fusion. Based on our comprehensive review of the literature, prospective, randomized studies with a focus on long-term pain control and fusion rates after SIJ fusion are lacking in the neurosurgical and orthopedic literature. Further, well-designed studies are necessary to better understand the surgical and clinical efficacy of SIJ fusion.

\section{References}

1. Al-Khayer A, Hegarty J, Hahn D, Grevitt MP: Percutaneous sacroiliac joint arthrodesis: a novel technique. J Spinal Disord Tech 21:359-363, 2008

2. Belanger TA, Dall BE: Sacroiliac arthrodesis using a posterior midline fascial splitting approach and pedicle screw instrumentation: a new technique. J Spinal Disord 14:118-124, 2001

3. Bernard TN Jr, Kirkaldy-Willis WH: Recognizing specific characteristics of nonspecific low back pain. Clin Orthop Relat Res (217):266-280, 1987

4. Berthelot JM, Gouin F, Glemarec J, Maugars Y, Prost A: Possible use of arthrodesis for intractable sacroiliitis in spondylarthropathy: report of two cases. Spine (Phila Pa 1976) 26:2297-2299, 2001

5. Buchowski JM, Kebaish KM, Sinkov V, Cohen DB, Sieber AN, Kostuik JP: Functional and radiographic outcome of sacroiliac arthrodesis for the disorders of the sacroiliac joint. Spine J 5:520-529, 2005

6. Cohen SP: Sacroiliac joint pain: a comprehensive review of anatomy, diagnosis, and treatment. Anesth Analg 101:14401453,2005

7. Cummings J Jr, Capobianco RA: Minimally invasive sacroil- 
iac joint fusion: one-year outcomes in 18 patients. Ann Surg Innov Res 7:12, 2013

8. Deyo RA, Mirza SK, Martin BI: Back pain prevalence and visit rates: estimates from U.S. national surveys, 2002. Spine (Phila Pa 1976) 31:2724-2727, 2006

9. Duhon BS, Cher DJ, Wine KD, Lockstadt H, Kovalsky D, Soo CL: Safety and 6-month effectiveness of minimally invasive sacroiliac joint fusion: a prospective study. Med Devices (Auckl) 6:219-229, 2013

10. Ebraheim NA, Ramineni SK, Alla SR, Ebraheim M: Sacroiliac joint fusion with fibular bone graft in patients with failed percutaneous iliosacral screw fixation. J Trauma 69:1226-1229, 2010

11. Foley BS, Buschbacher RM: Sacroiliac joint pain: anatomy, biomechanics, diagnosis, and treatment. Am J Phys Med Rehabil 85:997-1006, 2006

12. Giannikas KA, Khan AM, Karski MT, Maxwell HA: Sacroiliac joint fusion for chronic pain: a simple technique avoiding the use of metalwork. Eur Spine J 13:253-256, 2004

13. Khurana A, Guha AR, Mohanty K, Ahuja S: Percutaneous fusion of the sacroiliac joint with hollow modular anchorage screws: clinical and radiological outcome. J Bone Joint Surg Br 91:627-631, 2009

14. Kibsgård TJ, Røise $\mathrm{O}$, Sudmann E, Stuge B: Pelvic joint fusions in patients with chronic pelvic girdle pain: a 23 -year follow-up. Eur Spine J 22:871-877, 2013

15. Ledonio CG, Polly DW Jr, Swiontkowski MF: Minimally invasive versus open sacroiliac joint fusion: are they similarly safe and effective? Clin Orthop Relat Res 472:1831-1838, 2014

16. Liliang PC, Lu K, Liang CL, Tsai YD, Wang KW, Chen HJ: Sacroiliac joint pain after lumbar and lumbosacral fusion: findings using dual sacroiliac joint blocks. Pain Med 12:565-570, 2011

17. Maigne JY, Planchon CA: Sacroiliac joint pain after lumbar fusion. A study with anesthetic blocks. Eur Spine J 14:654 658,2005

18. Papanastassiou ID, Setzer M, Eleraky M, Baaj AA, Nam $\mathrm{T}$, Binitie $\mathrm{O}$, et al: Minimally invasive sacroiliac fixation in oncologic patients with sacral insufficiency fractures using a fluoroscopy-based navigation system. J Spinal Disord Tech 24:76-82, 2011

19. Rudolf L: Sacroiliac joint arthrodesis-MIS technique with titanium implants: report of the first 50 patients and outcomes. Open Orthop J 6:495-502, 2012

20. Sachs D, Capobianco R: Minimally invasive sacroiliac joint fusion: one-year outcomes in 40 patients. Adv Orthop 2013:536128, 2013

21. Schütz U, Grob D: Poor outcome following bilateral sacroiliac joint fusion for degenerative sacroiliac joint syndrome. Acta Orthop Belg 72:296-308, 2006

22. Schwarzer AC, Aprill CN, Derby R, Fortin J, Kine G, Bogduk N: The prevalence and clinical features of internal disc disruption in patients with chronic low back pain. Spine (Phila Pa 1976) 20:1878-1883, 1995

23. Sembrano JN, Polly DW Jr: How often is low back pain not coming from the back? Spine (Phila Pa 1976) 34:E27-E32, 2009

24. Stark JG, Fuentes JA, Fuentes TI, Idemmili C: The history of sacroiliac joint arthrodesis: a critical review and introduction of a new technique. Curr Orthop Pract 22:545-557, 2011

25. Wise CL, Dall BE: Minimally invasive sacroiliac arthrodesis: outcomes of a new technique. J Spinal Disord Tech 21:579-584, 2008

\section{Author Contributions}

Conception and design: Dickman, Zaidi. Acquisition of data: Zaidi, Montoure. Analysis and interpretation of data: Zaidi, Montoure. Drafting the article: Zaidi, Montoure. Critically revising the article: Dickman, Zaidi. Reviewed submitted version of manuscript: Dickman, Zaidi. Administrative/technical/material support: Dickman. Study supervision: Dickman.

\section{Correspondence}

Curtis A. Dickman, c/o Neuroscience Publications, Barrow Neurological Institute, St. Joseph's Hospital and Medical Center, 350 W. Thomas Rd., Phoenix, AZ 85013.email: neuropub@ dignityhealth.org. 